\title{
Identifying the Viral Genes Encoding Envelope Glycoproteins for Differentiation of Cyprinid herpesvirus 3 Isolates
}

\author{
Jee Eun Han ${ }^{1}$, Ji Hyung Kim ${ }^{2}$, Tristan Renault ${ }^{3}$, Casiano Choresca Jr. ${ }^{1}$, Sang Phil Shin ${ }^{1}$, \\ Jin Woo Jun ${ }^{1}$ and Se Chang Park ${ }^{1}$ *
}

1 Laboratory of Aquatic Biomedicine, College of Veterinary Medicine and Research Institute for Veterinary Science, Seoul National University, Seoul, 151-742, Republic of Korea;

E-Mails: yellowjeeeun@hanmail.net (J.E.H.); cassey2002@yahoo.com (C.C.); charisma-shin@hanmail.net (S.P.S.); advancewoo@hanmail.net (J.W.J.)

2 Korea Ocean Research and Development Institute, Ansan, 426-744, Republic of Korea; E-Mail: mephisto81@ @anmail.net

3 Institut Francais de Recherche pour l'Exploitation de la Mer (IFREMER), Laboratoire de Génétique et Pathologie (LGP), Avenue de Mus de Loup, 17390 La Tremblade, France;

E-Mail: Tristan.Renault@ifremer.fr

* Author to whom correspondence should be addressed; E-Mail: parksec@ @nu.ac.kr; Tel.: +82-2-880-1282; Fax: +82-2-880-1213.

Received: 3 January 2013; in revised form: 23 January 2013 / Accepted: 25 January 2013 / Published: 31 January 2013

\begin{abstract}
Cyprinid herpes virus 3 (CyHV-3) diseases have been reported around the world and are associated with high mortalities of koi (Cyprinus carpio). Although little work has been conducted on the molecular analysis of this virus, glycoprotein genes identified in the present study seem to be valuable targets for genetic comparison of this virus. Three envelope glycoprotein genes (ORF25, 65 and 116) of the CyHV-3 isolates from the USA, Israel, Japan and Korea were compared, and interestingly, sequence insertions or deletions were observed in these target regions. In addition, polymorphisms were presented in microsatellite zones from two glycoprotein genes (ORF65 and 116). In phylogenetic tree analysis, the Korean isolate was remarkably distinguished from USA, Israel, Japan isolates. These findings may be suitable for many applications including isolates differentiation and phylogeny studies.
\end{abstract}


Keywords: Cyprinid herpes virus 3; glycoprotein gene; Koi herpesvirus; microsatellite; polymorphism; phylogenetic tree

\section{Introduction}

The production of ornamental fish is an important component of the aquaculture industry in several countries [1]. In particular, the commercial production of koi (Cyprinus carpio) has grown to become a major part of the pet industry within the past few decades, and koi trade plays an important role in meeting the increasing global demand [2].

Koi herpesvirus (KHV) disease, a highly contagious and virulent disease of carp and koi, was first recognized and documented in Germany in 1997 [3]. KHV is a double-stranded DNA virus belonging to the order Herpesvirales, family Alloherpesviridae, under the formal designation Cyprinid herpes virus 3 (CyHV-3) [4-5].

Members of the order Herpesvirales consist of a linear, double-stranded DNA genome packaged within an icosahedral capsid of characteristic architecture that is surrounded by a proteinaceous tegument layer and finally by a host-derived envelope containing virus glycoproteins [6]. Glycoproteins, which are major component of the virion envelope and relevant for virus-host cell interactions and for the host immune response [7-9], have been targets for serological markers or vaccine candidates and have also been used for a phylogenetic analysis in the order Herpesvirales [10-12].

In this study, three CyHV-3 envelope glycoprotein genes were amplified from Korean isolate and the sequences were compared with previously reported CyHV-3 from the USA, Israel and Japan. Subsequently, microsatellite polymorphisms were analyzed from two glycoprotein genes and phylogenetic trees based on these genes were described.

\section{Results and Discussion}

\subsection{Analysis of CyHV-3 Envelope Glycoprotein Sequences}

Three selected regions of envelope glycoprotein genes from the Korean CyHV-3 were amplified and sequenced. These genes, encoded by ORF25, ORF65 and ORF116, are considered to encode the major envelope glycoproteins of this virus [7]. From the sequence analysis results, the ORF25, ORF65, and ORF116 regions of CyHV-3 from Korea, the USA, Israel, and Japan showed some sequence variations including several additions and deletions (Figure 1-3).

In the ORF65 region from Korean CyHV-3, the sequence insertion consisted of three consecutive nucleic acids in a repeated region of trinucleotides characterized by a "CAC" pattern, and the sequence deletion consisted of three consecutive nucleic acids in a repeated region of trinucleotides characterized by a "ACC" pattern (microsatellite zone) (Figure 2). Additionally, the microsatellite zone, characterized by a "CTTCATCTT" pattern, presented in ORF116, and a sequence deletion consisting of 27 consecutive nucleic acids in this repeated region was observed in Korean CyHV-3 (Figure 3). 
Polymorphisms were also observed amongst American, Israeli, and Japanese CyHV-3 in these microsatellite zones; therefore, the microsatellite polymorphism of CyHV-3 determined in this study may be suitable for many applications including isolates differentiation and phylogenic studies. Microsatellites have been used to characterize different isolates, particularly in herpes cytomegaloviruses [13-14] and more recently in herpes simplex viruses [15] and in Ostreid herpes virus $1[16]$.

Figure 1. Nucleotide sequences of the glycoprotein gene (open reading frame [ORF]25) of the Korean CyHV-3 (KHV-K) and those of the USA (KHV-U), Israel (KHV-I), and Japan (KHV-J) CyHV-3 were aligned using BioEdit software. A sequence insertion (18 bp) was observed in Korean CyHV-3 (KHV-K).

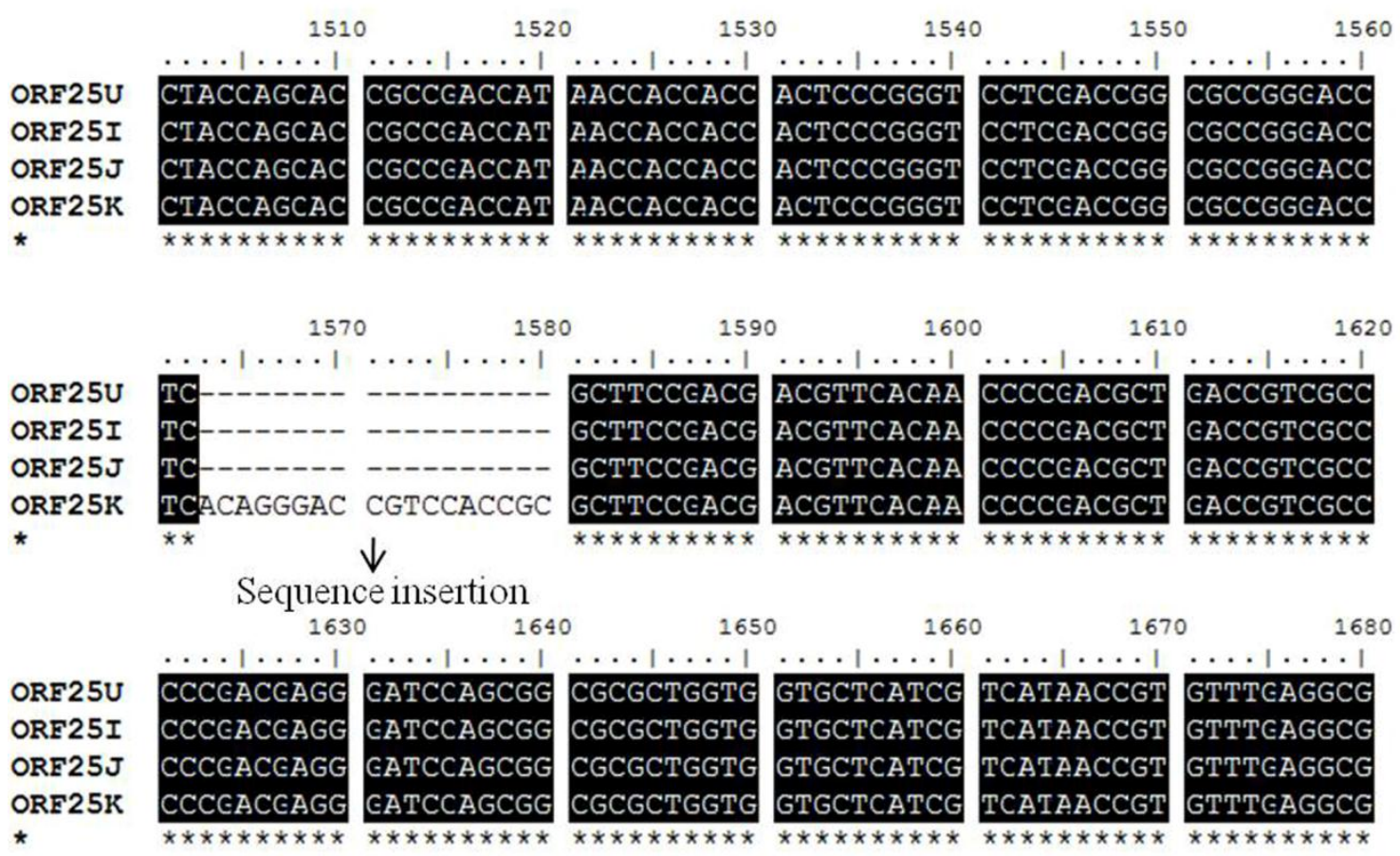


Figure 2. Nucleotide sequences of the glycoprotein gene (open reading frame [ORF]65) of Korean CyHV-3 (KHV-K) and those of the USA (KHV-U), Israel (KHV-I), and Japan (KHV-J) CyHV-3 were aligned using BioEdit software. Two microsatellite zones were observed, and both sequence insertions and deletions were observed in KHV-K.

Microsatellite zone

$\begin{array}{rrrrrr}370 & 380 & 390 & 400 & 410 & 420\end{array}$

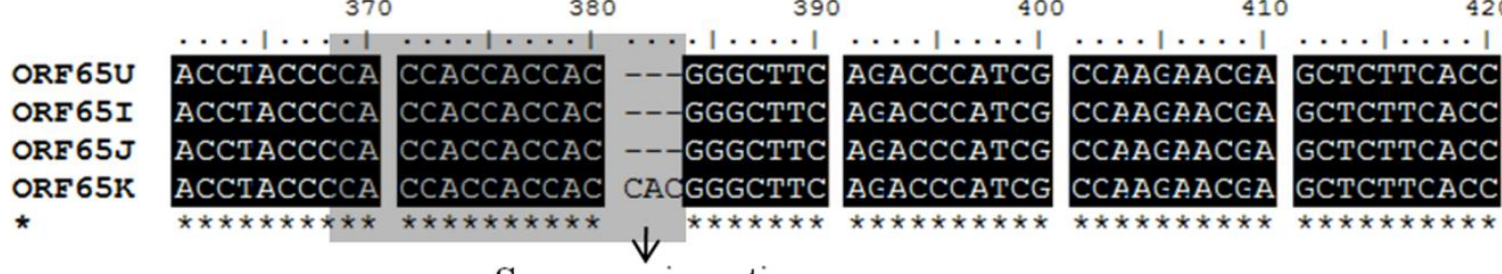

Sequence insertion

Microsatellite zone

\begin{tabular}{|c|c|c|c|c|c|c|}
\hline & 1390 & 1400 & 1410 & 1420 & 1430 & 1440 \\
\hline ORF65U & AACGGCACCA & GGATCAAGCA & GTTATTTGTC & ААССТССССА & CCACCACCAC & CACCACCACC \\
\hline ORF65I & AACGGCACCA & GGATCAAGCA & GTTATTTGTC & AАCCTCCCCA & CCACCACCAC & CACCACCACC \\
\hline ORE65J & AACGGCACCA & GGATCAAGCA & GTTATTTGTC & AACCTCCCCA & CCACCACCAC & CACCACCACC \\
\hline ORF 65K & AACGGCACCA & GGATCAAGCA & GTTATTTGTC & AACCTCCCCA & CCACCACCAC & CACCACCACC \\
\hline
\end{tabular}

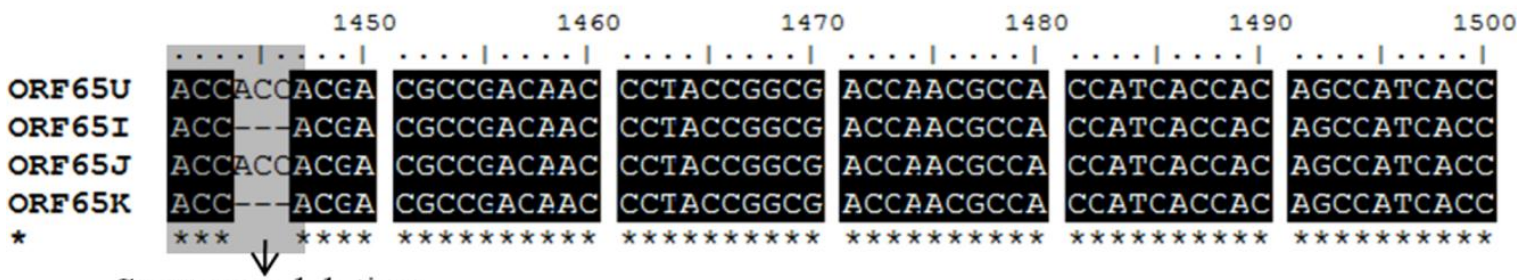

Sequence deletion

Figure 3. Nucleotide sequences of the glycoprotein gene (open reading frame [ORF]116) of Korean CyHV-3 (KHV-K) and those of the USA (KHV-U), Israel (KHV-I), and Japan (KHV-J) CyHV-3 were aligned using BioEdit software. Several sequence deletions were observed in the microsatellite zone in KHV-K.

Microsatellite zone

610

620 640 650 660

ORF116U ORF116I ORF116J ORF116K *

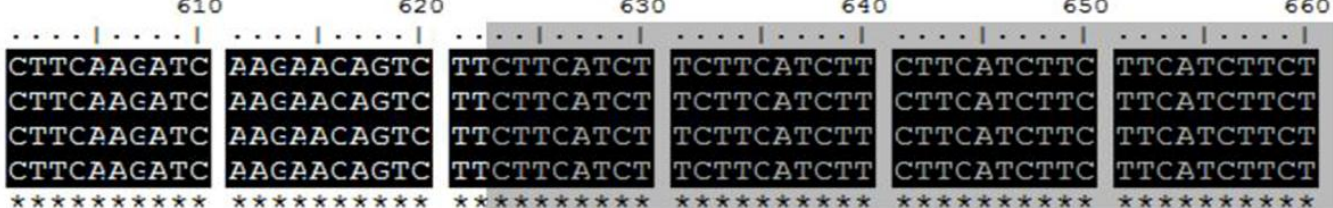

ORF116U ORF116I ORF116J ORE116K *
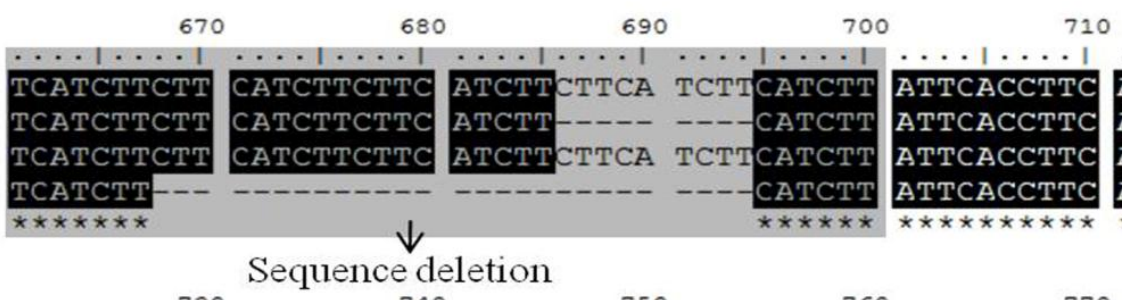
10720

ORF116U ORF116I ORF116J ORF116K 760 


\subsection{Phylogenetic Analysis of CyHV-3 Envelope Glycoprotein Genes}

In phylogenetic trees (Figure 4A-C), sequences from the USA (KHV-U), Israel (KHV-I), and Japan (KHV-J) CyHV-3 were clustered into one group, but amplified sequences from the Korean CyHV-3 (KHV-K) was highly distinguished from this group.

In that previous report [17], a CyHV-3 isolate from Korea was compared with known CyHV-3 isolates and clustered into the same group based on sequence similarity (100\%). A phylogenetic analysis based on the conserved region (ORF90) did not genetically distinguish the Korean isolate from the reference CyHV-3 isolates. However, envelope glycoprotein gene regions targeted in this study showed polymorphisms, indicating that the Korean CyHV-3 isolate was genetically different from those of the USA, Israel, and Japan isolates.

Figure 4. Phylogenetic trees were conducted on the sequences of the glycoprotein gene (open reading frame [ORF]25, ORF65 and ORF116) from Korea (KHV-K), the USA (KHV-U), Israel (KHV-I), and Japan (KHV-J) CyHV-3.

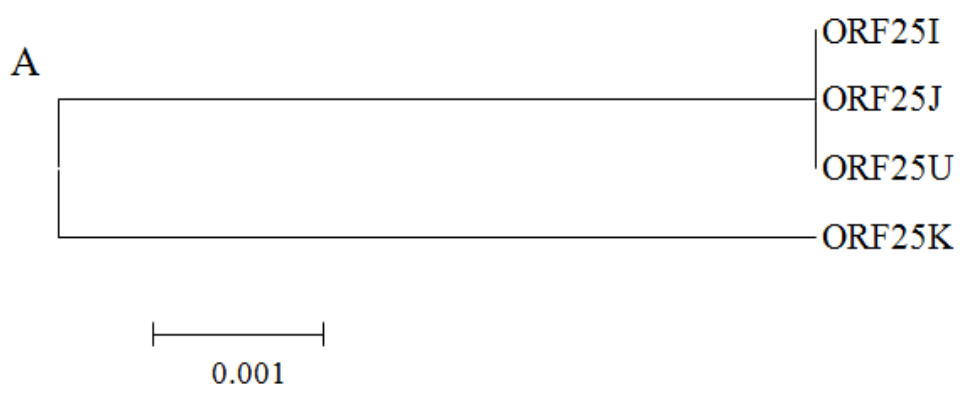

B
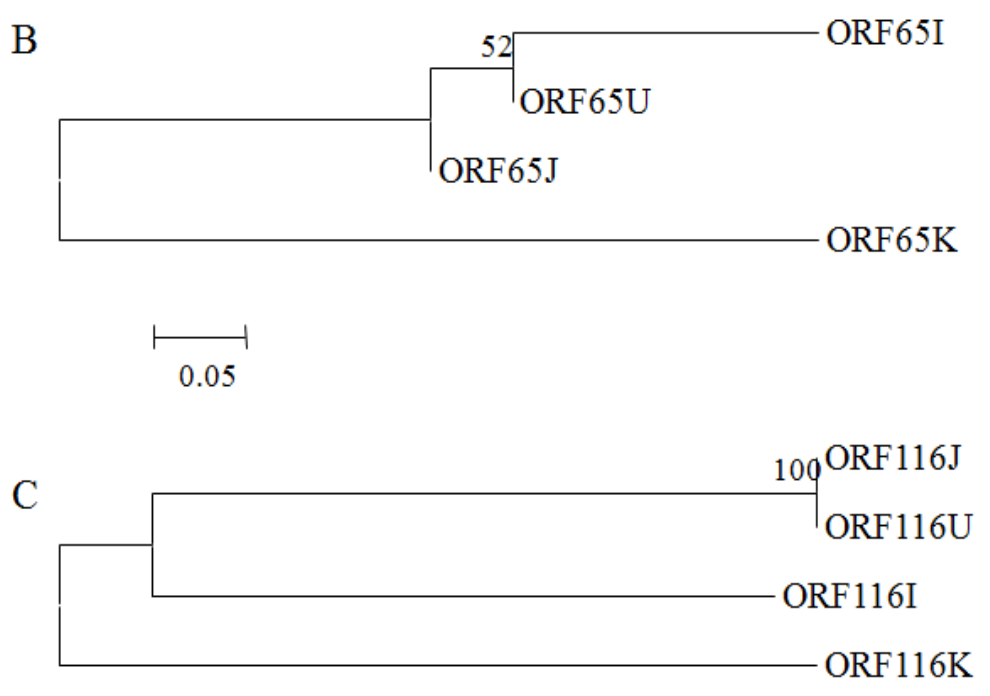

0.02 


\section{Experimental Section}

\subsection{Virus and Viral DNA}

Viral DNA was extracted from the gill of koi [17] using the DNeasy Tissue Extraction kit (Qiagen, Valencia, CA, USA) according to the manufacturer's instructions, and samples were stored at $-80^{\circ} \mathrm{C}$ until use.

\subsection{Amplification of Korean CyHV-3 Glycoprotein Genes}

To acquire the full-length open reading frame (ORF) of potential envelope glycoprotein genes, three representative regions (ORF25, ORF65, and ORF116; 1,806 bp, 1,791 bp, and 855 bp, respectively) were chosen. Primers (Table 1) were designed from three full CyHV-3 genome sequences from the USA (KHV-U), Israel (KHV-I), and Japan (KHV-J), which were available in GenBank (DQ657948, DQ177346, and NC009127, respectively).

The polymerase chain reaction (PCR) reaction was performed in a final volume of $50 \mu$ containing $100 \mathrm{ng}$ total genomic DNA, $5 \mu 110 \times$ Taq-Buffer, $4 \mu 110 \mathrm{mM}$ dNTP's, 1 U of platinum Taq DNA polymerase (Invitrogen, Carlsbad, CA, USA) and 2 pmol of each primer. After initial denaturation at $95{ }^{\circ} \mathrm{C}$ for $30 \mathrm{~s}$, amplification was conducted for 30 cycles under the following conditions: $30 \mathrm{~s}$ at $95{ }^{\circ} \mathrm{C}, 1 \mathrm{~min}$ at the annealing temperature, and $1.5 \mathrm{~min}$ at $72{ }^{\circ} \mathrm{C}$. Cycling was followed by a final extension for $7 \mathrm{~min}$ at $72{ }^{\circ} \mathrm{C}$. Annealing temperatures of $62{ }^{\circ} \mathrm{C}, 63{ }^{\circ} \mathrm{C}$, and $48{ }^{\circ} \mathrm{C}$ were used to amplify ORF25, ORF65, and ORF116, respectively. The PCR products were purified using a QIAquick PCR purification kit (Qiagen), according to the manufacturer's instructions. Purified PCR products were ligated into the pTOP TA V2 plasmid vector using a TOP Cloner PCR Cloning kit (Enzynomics, Seoul, Korea), and this plasmid was transformed into competent DH5 $\alpha$ (Enzynomics). Recombinant plasmids were extracted via the alkaline lysis procedure [18] and sequencing was carried out by the Macrogen Genomic Division, Seoul, Korea using ABI PRISM Big Dye TM Terminator Cycle Sequencing technology (Applied BioSystems, Foster City, CA, USA). Electrophoresis of sequencing reactions was completed using an automated ABI PRISM 3730XL DNA Sequencing System (Applied BioSystems). The sequences were subsequently analyzed with the AlignX tool in the Vector NTI program(Invitrogen). BLAST searches were carried out using both the blastn and blastx algorithms [19] against the National Center for Biotechnology Information.

\subsection{Analysis of Korean CyHV-3 Glycoprotein Genes}

Alignment of the glycoprotein gene nucleotide sequences of the Korean CyHV-3 (KHV-K) with those of the USA (KHV-U), Israel (KHV-I), and Japan (KHV-J) CyHV-3 were generated using BioEdit software version [20].

Also, the phylogenetic analysis was conducted using Bioedit software and Molecular Evolutionary Genetics Analysis (MEGA) 5 software, with bootstrap values calculated from 1000 replicates. The neighbor-joining method was used to construct the phylogenetic tree. 
Table 1. Primers used in this study.

\begin{tabular}{|c|c|c|}
\hline Primer name & Sequence $\left(5^{\prime} \rightarrow 3^{\prime}\right)$ & Purpose \\
\hline \multicolumn{3}{|l|}{ ORF25 } \\
\hline $\begin{array}{l}25 \mathrm{~F} 1 \\
25 \mathrm{R} 1\end{array}$ & $\begin{array}{l}\text { ATGACGGGTTGTGGGGTTTGG } \\
\text { TTAGGGCCTCCGGGAAACCTG }\end{array}$ & Full length CDS \\
\hline $\begin{array}{l}25(\mathrm{~m}) \mathrm{F} 1 \\
25(\mathrm{~m}) \mathrm{R} 1\end{array}$ & $\begin{array}{l}\text { GCGTCTCGGGAGATACTTTG } \\
\text { GGGCACTCCATCTCAAAGAC }\end{array}$ & Internal region \\
\hline \multicolumn{3}{|l|}{ ORF65 } \\
\hline $\begin{array}{l}65 \mathrm{~F} 1 \\
65 \mathrm{R} 1\end{array}$ & $\begin{array}{l}\text { ATGGTCTCGCCGCTCGTCGTC } \\
\text { CTACTTGATGGTCGCGGCGGC }\end{array}$ & Full length CDS \\
\hline \multicolumn{3}{|l|}{ ORF116 } \\
\hline $\begin{array}{l}116 \mathrm{~F} 1 \\
116 \mathrm{R} 1\end{array}$ & $\begin{array}{l}\text { ATGAGACTTTTTCTCCTCGTC } \\
\text { TCAAACTTTTGGTGATGAAAA }\end{array}$ & Full length CDS \\
\hline
\end{tabular}

\subsection{Nucleotide Sequence Accession Numbers}

Newly amplified sequences of glycoprotein genes of Korean CyHV-3 were deposited in the GenBank nucleotide sequence database with the following accession numbers: JQ308816 for ORF25, JQ308817 for ORF65, and JQ308819 for ORF116.

\section{Conclusions}

Glycoprotein gene regions targeted in this study showed polymorphisms, indicating that the Korean CyHV-3 isolate was genetically different from those of the USA, Israel, and Japan isolates. Amplified sequences of the Korean CyHV-3 isolate contained several sequence insertions or deletions compared to those of reference CyHV-3. The ORF116 region presented as a sequence insertion (12 bp) in a microsatellite area of CyHV-3 from Korea. In addition, the ORF65 region had an insertion (3 bp) and a deletion ( $3 \mathrm{bp}$ ) in two microsatellite areas. As the data in microsatellite zones, amplified glycoprotein gene sequence of the Korean CyHV-3 (KHV-K) was distinguished from those of the USA (KHV-U), Israel (KHV-I), and Japan (KHV-J) CyHV-3 in the phylogenetic tree.

In this study, we successfully identified the putative envelope glycoprotein genes of CyHV-3 and analyzed sequences showed polymorphisms in microsatellite zones. These data could provide the genetic background for epidemiology studies.

\section{Acknowledgments}

This study was financially supported by Basic Science Research Program (2010-0016748) through the National Research Foundation of Korea (NRF) funded by the Ministry of Education, Science and Technology, by Korea Research Foundation Grant (KRF-2008-331-E00385).

\section{Conflict of Interest}

The authors declare no conflict of interest. 


\section{References}

1. Whittington, R.; Chong, R. Global trade in ornamental fish from an Australian perspective: The case for revised import risk analysis and management strategies. Prev. Vet. Med. 2007, $81,92-116$.

2. David, L.; Rothbard, S.; Rubinstein, I.; Katzman, H.; Hulata, G.; Hillel, J.; Lavi, U. Aspects of red and black color inheritance in the Japanese ornamental (Koi) carp (Cyprinus carpio L.). Aquaculture 2004, 233, 129-147.

3. Bretzinger, A.; Fischer-Scherl, T.; Oumouma, M.; Hoffmann, R.; Truyen, U. Mass mortalities in koi, Cyprinus carpio, associated with gill and skin disease. Bull. Eur. Assoc. Fish Pathol. 1999, 19, 182-185.

4. Waltzek, T.B.; Kelley, G.O.; Stone, D.M.; Way, K.; Hanson, L.; Fukuda, H.; Hirono, I.; Aoki, T.; Davison, A.J.; Hedrick, R.P. Koi herpesvirus represents a third cyprinid herpesvirus (CyHV-3) in the family Herpesviridae. J. Gen. Virol. 2005, 86, 1659-1667.

5. Davison, A.J. Herpesvirus systematics. Vet. Microbiol. 2010, 143, 52-69.

6. Davison, A.J.; Eberle, R.; Hayward, G.S.; McGeoch, D.J.; Minson, A.C.; Pellett, P.E.; Roizman, B.; Studdert, M.J.; Thiry, E. Herpesviridae, In Virus Taxonomy: Eighth Report of the International Committee on Taxonomy of Viruses, 1st Edition; Fauquet, C.M., Mayo, A.A., Maniloff, J., Desselberger, U., Ball, L.A., Eds; Elsevier: Academic Press, Amsterdam, The Netherlands, 2005; pp. 193-212.

7. Aoki, T.; Hirono, I.; Kurokawa, K.; Fukuda, H.; Nahary, R.; Eldar, A.; Davison, A.J.; Waltzek, T.B.; Bercovier, H.; Hedrick, R.P. Genome sequences of three koi herpesvirus isolates representing the expanding distribution of an emerging disease threatening koi and common carp worldwide. J. Virol. 2007, 81, 5058-5065.

8. Davison, A.J.; Davison, M.D. Identification of structural proteins of channel catfish virus by mass spectrometry. Virology 1995, 206, 1035-1043.

9. Kucuktas, H.; Brady, Y.J.; Tuzun, S. Cloning and expression of a putative glycoprotein gene of channel catfish virus using baculovirus expression system. Dis. Aquat. Organ. 1998, 34, 231-237.

10. Dubin, G.; Socolof, E.; Frank, I.; Friedman, H. Herpes simplex virus type 1 Fc receptor protects infected cells from antibody-dependent cellular cytotoxicity. J. Virol. 1991, 65, 7046-7050.

11. Dunowska, M.; Letchworth, G.J.; Collins, J.K.; DeMartini, J.C. Ovine herpesvirus-2 glycoprotein $B$ sequences from tissues of ruminant malignant catarrhal fever cases and healthy sheep are highly conserved. J. Gen. Virol. 2001, 82, 2785-2790.

12. Kaashoek, M.; Moerman, A.; Madic, J.; Rijsewijk, F.; Quak, J.; Gielkens, A.; Van Oirschot, J. A conventionally attenuated glycoprotein E-negative strain of bovine herpesvirus type 1 is an efficacious and safe vaccine. Vaccine 1994, 12, 439-444.

13. Davis, C.L.; Field, D.; Metzgar, D.; Saiz, R.; Morin, P.A.; Smith, I.L.; Spector, S.A.; Wills, C. Numerous length polymorphisms at short tandem repeats in human cytomegalovirus. J. Virol. 1999, 73, 6265-6270.

14. Picone, O.; Ville, Y.; Costa, J.M.; Rouzioux, C.; Leruez-Ville, M. Human cytomegalovirus (HCMV) short tandem repeats analysis in congenital infection. J. Clin. Virol. 2005, 32, 254-256. 
15. Deback, C.; Boutolleau, D.; Depienne, C.; Luyt, C.E.; Bonnafous, P.; Gautheret, A.; Garrigue, I.; Agut, H. Utilization of microsatellite polymorphism for differentiating herpes simplex virus type 1 strains. J. Clin. Microbiol. 2009, 47, 533-540.

16. Segarra, A.; Pepin, J.F.; Arzul, I.; Morga, B.; Faury, N.; Renault, T. Detection and description of a particular Ostreid herpesvirus 1 genotype associated with massive mortality outbreaks of Pacific oysters, Crassostrea gigas, in France in 2008. Virus Res. 2010, 153, 92-99.

17. Gomez, D.K.; Joh, S.J.; Jang, H.; Shin, S.P.; Choresca, C.H. Jr.; Han, J.E.; Kim, J.H.; Jun, J.W.; Park, S.C. Detection of Koi Herpesvirus (KHV) from Koi (Cyprinus carpio koi) Broodstock in Korea. Aquaculture 2011, 311, 42-47.

18. Kado, C.I.; Liu, S.T. Rapid procedure for detection and isolation of large and small plasmids. J. Bacteriol. 1981, 145, 1365-1373.

19. Altschul, S.F.; Gish, W.; Miller, W.M.; Eyers, E.W.; Lipman, D.J. Basic local alignment search tool. J. Mol. Biol. 1990, 215, 403-410.

20. Hall, T. BioEdit: A user-friendly biological sequence alignment editor and analysis program for Windows 95/98/NT. Nucleic Acids Symp. Ser. 1999, 41, 95-98.

(C) 2013 by the authors; licensee MDPI, Basel, Switzerland. This article is an open access article distributed under the terms and conditions of the Creative Commons Attribution license (http://creativecommons.org/licenses/by/3.0/). 